\title{
The relationship between dietary intake and stunting among pre-school children in Upper Egypt
}

\author{
Eman Mohamed Mahfouz, Eman Sameh Mohammed, Shaza Fadel Alkilany* $₫$ and \\ Tarek Ahmed Abdel Rahman \\ Public Health and Preventive Medicine Department, Faculty of Medicine, Minia University, Minia 61519, Egypt
}

Submitted 1 June 2020: Final revision received 11 August 2021: Accepted 6 September 2021: First published online 9 September 2021

\begin{abstract}
Objective: Linear growth is controlled by several factors, malnutrition is one of the leading causes of stunted child growth. The objective of this study was to determine the dietary intakes associated with stunting among pre-school children in rural Upper Egypt.

Design: Community-based cross-sectional study

Setting: Data were collected by interviewing the children's caregivers in the rural household setting.

Participants: The study included 497 pre-school children aged 2-5 years in rural Upper Egypt. Food intake data were estimated using 24-h recall method. Anthropometric measurements of children were taken and then converted to Z-scores for weight-for-age Z-score, height-for-age Z-score and weight-for-height Z-score.

Results: The study included 497 children of which $19 \cdot 1 \%$ were stunted, $76.3 \%$ did not meet recommended energetic intake and $13.7 \%$ did not meet recommended protein intake and this was significantly higher than non-stunted children. Children who were stunted significantly consumed poultry, eggs and fruits less often than non-stunted children, by regression; male sex (adjusted odds ratio $(\mathrm{aOR})=1.91)$, mother's age (0.93), lower socio-economic status (SES); and not meeting recommended protein intake $(\mathrm{aOR}=2 \cdot 26$ ) were found to be associated with stunting. Conclusion: Male sex, younger mothers, lower SES and not meeting recommended energy and protein were statistically associated with stunting. Nutrition education messages encouraging adequate and healthy eating are recommended.
\end{abstract}

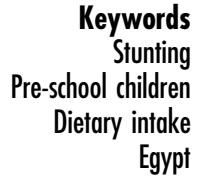

Stunting

-school children

Egypt
Growth was previously identified as a 'mirror of the conditions of society', especially the 'nutritional and hygienic status' of the population ${ }^{(1)}$. Stunting (short stature for age) is the most commonly used indicator of chronic malnutrition and is assessed by anthropometric measures of the child's height for age ${ }^{(2)}$. Globally, the prevalence of stunting fell from $29.5 \%$ to $22.9 \%$ between 2005 and 2016, although 155 million children under 5 years of age across the world still suffer from stunted growth, ranging from nearly $2 \%$ in high-income countries to more than $50 \%$ in low-income countries ${ }^{(3,4)}$. According to Egypt Demographic and Health Survey (EDHS) 2014, one in five Egyptian children under 5 years of age was stunted (short for their age) and $24.8 \%$ of children of rural Upper Egypt were stunted ${ }^{(5)}$. In Minia, it was found that $20 \cdot 3 \%$ of children aged 6-24 months were stunting ${ }^{(6)}$.
Linear growth is controlled by complex genetic, physiological and nutrient-sensitive endocrine/paracrine/autocrine-mediated molecular signalling mechanisms, possibly including sleep adequacy through its influence on growth hormone secretion ${ }^{(7)}$.

In global settings of poverty, malnutrition is often driven by energetic scarcity which, along with infection, is one of the leading causes of stunted child growth ${ }^{(8)}$. Deficiency in protein and $\mathrm{Zn}$ is associated with poverty and results in decreased linear growth. $\mathrm{Zn}$ is found in red meat and poultry and humans do not have $\mathrm{Zn}$ tissue reserves. Therefore, when dietary intake is inadequate, a child's linear growth decreases $^{(9)}$. Other micronutrients deficiency like vitamin $\mathrm{A}$ and $\mathrm{Fe}$ deficiencies cause growth flattering when the deficiency is severe ${ }^{(10)}$.

Childhood stunting is associated with increased risk for adult diseases (e.g. obesity, CVD and diabetes), and with

**Corresponding autbor: Email shazafadel18@gmail.com

(C) The Author(s), 2021. Published by Cambridge University Press on behalf of The Nutrition Society. This is an Open Access article, distributed under the terms of the Creative Commons Attribution licence (https://creativecommons.org/licenses/by/4.0/), which permits unrestricted re-use, distribution, and reproduction in any medium, provided the original work is properly cited. 
suboptimal brain development, which leads to impaired cognitive ability and school performance, and reduces earning potential later in life ${ }^{(9)}$.

One study demonstrated that high consumption of animal products was associated with the decreased risk of maternal-child double burden which was defined by the coexistence of maternal overweight and child stunting within the same household. Therefore, improving child stunting through adequate intake of animal products is critical to solve the problem of maternal-child double burden $^{(11)}$

Egypt has floated its currency in November 2016, leading to reduction of its value by almost $50 \%$ against the dollar. Although the liberalisation should help the country to strengthen its economy, it makes life harder for Egyptians because the cost of goods and price of foods has risen sharply over the past few years ${ }^{(12)}$. Assessing relationship between stunting and dietary pattern is important, especially after floating of Egyptian currency. Early deficits in childhood growth and development contribute to long-term problems that can persist into adulthood ${ }^{(13)}$. Understanding of the patterns and factors associated with stunting could enable nutrition programmes to target nutritionally vulnerable individuals.

The objective of this study was to determine dietary intakes associated with stunting among pre-school children in rural Upper Egypt.

\section{Methods}

\section{Study design and participants}

This cross-sectional study was conducted during the period from November 2017 to March 2018. The study population consisted of children aged 2-5 years of age and their caregivers in rural Upper Egypt. Children having chronic diseases (e.g. cerebral palsy, asthma or diabetes, cardiac, renal or liver diseases) or taking medications that may affect their dietary intake and/or the overall nutritional status were excluded. In households with more than one child aged $2-5$ years, the youngest child was selected.

\section{Sampling methods and sample size}

A random sampling was done to select one district out of the nine districts of the studied area; then one village was chosen randomly, considering that the district had homogenous characteristics. All households with a child aged 2 to 5 years of age had an equal chance of being asked to participate in the survey.

A required sample size of 258 children was estimated taking into account prevalence of stunting in Egypt of $21.4 \%$ based on Egypt demographic health survey ${ }^{(14)}$ to provide $96 \%$ power at the level of $5 \%$ significance using the statistical software EPI-INFO 7.2.2.6. The actual sample collected was 497 children. Non-response rate was $4.1 \%$

\section{Data collection}

Data were collected by face-to-face interviews in the household setting using a multi-component questionnaire; the aim of the study was explained. With the help of the local health facilities of the chosen areas, two health visitors contacted the target families. At the visit, the investigators introduced themselves to the head of the household and obtained verbal approval for participation in the study.

\section{Measures}

The items in the questionnaire included:

\section{Anthropometric measures}

Digital scale was used to measure weight to the nearest $0 \cdot 1$ $\mathrm{kg}$. A stretch-resistant measuring tape was used to measure standing height to the nearest $0.5 \mathrm{~cm}$. A big, flat, set square was used to make a right angle with the wall to ensure that height was measured accurately. Participants were asked to remove shoes and bulky clothes before measurements ${ }^{(15)}$. Mid-upper arm circumference (MUAC) was measured on the right arm using a non-elastic tape held midway between the acromion and the olecranon processes, with arm hanging loosely at the side of the body. MUAC-for-age $z$-score (MUACZ) was calculated using WHO Anthro software (version $3 \cdot 2 \cdot 2.)^{(16)}$.

\section{Conversion of weight and height to Z-score}

Each child's height-for-age Z-score (HAZ), weight-for-age Z-score, weight-for-height Z-score, BMI-for-age Z-score and MUACZ for age and sex were calculated based on WHO Child Growth Standards software WHO Anthro (version 3.2.2, January 2011) ${ }^{(16)}$. Children were classified as being stunted, underweight or wasted on the basis of their HAZ, weight-for-age Z-score and weight-for-height $Z$-score, respectively, when their score was 2 SD below the reference median according to the $\mathrm{WHO}^{(17)}$. The mean HAZ/weight-for-age Z-score/weight-for-height Z-score/ BMI-for-age Z-score/MUACZ was calculated as well as the proportion of children 2 SD below the reference level.

\section{Dietary intake}

Data on diet had been collected using specially designed questionnaires to cover required information on: food intake (24-h recall) and dietary pattern 'food frequency' for selected items.

\section{4-b dietary recall}

Food consumption was assessed by quantitative 24-h dietary recall method applied on the past $24 \mathrm{~h}$ during a personal interview. In this method, mothers were asked to recall the exact foods and beverages her child consumed during the previous 24-h period, from the first intake in the morning until the last foods or beverages consumed at night (before going to bed or later, in the case of those who get up at midnight and eat and/or drink 
something $)^{(18)}$. Quantities of food and beverages were estimated using cups and household utensils commonly used then converted into grams ${ }^{(19)}$.

Nutrient analysis and the calculation of diet energy intake were performed using the software program NutriSurvey ${ }^{(20)}$, mixed-dishes not found in NutriSurvey databases were deconstructed into its basic constituents. Dietary components assessed included energy intake as kilojoules, intake of total fat grams per day $(\mathrm{g} / \mathrm{d})$, total carbohydrates $(\mathrm{g} / \mathrm{d})$ and proteins $(\mathrm{g} / \mathrm{d})$. Energy deficit for children was calculated by taking the difference between children intake of total energy and recommended daily allowance ${ }^{(21)}$.

\section{Food intake frequency}

Data were collected on the usual intake of commonly consumed foods during the prior 12 months (during the year followed floating of the Egyptian currency). The food items included meat, poultry, fish, egg, milk, milk products, fruits, vegetables, legumes, rice/macaroni and tubers. Selected food items were chosen based on commonly consumed foods validated using public health expert's knowledge about culturally specific foods. Intakes of different food items were assessed using short answer questions that asked 'How often do you eat each item per week?' Food frequency categories ranged from never or less than once per month to every day ${ }^{(22)}$

\section{Socio-economic status}

Socio-economic status (SES) was calculated according to El-Gilany et al. (2012) ${ }^{(23)}$, a modification of the old scoring system of Fahmy and El-Sherbini $(1983)^{(24)}$. The scale has seven domains with a total score of 84 , with a higher score indicating better SES. Total score was calculated by summing the score of the seven domains: education and cultural, occupation, family, family possessions, economic, home sanitation, and health care.

SES was classified to very low (score $<35$ ), low (score 35-41), middle (score 42-47) and high (score $\geq 48$ ) depending on the quartiles of the calculated score rather than a fixed point.

\section{Other measures}

The questionnaire included questions about mother's age, child's sex, number of children in the house and child birth order. Perceived size at birth was reported by mother, they were asked to put it in one category (lower than average, normal/average and higher than average).

\section{Statistical analysis}

Participants with missing information for key variables were excluded from the analysis. Normality of the data was tested using the Kolmogorov-Smirnov tests. Data are presented as mean and standard deviation. Comparison between unrelated variables was conducted with Student's $t$ test. The chi-square and Fisher's exact tests were used for comparison between categorical variables. Binary logistic regression analysis was used to determine which factors were significantly and independently associated with stunting after adjustment for potential confounders. Factors found to be significantly associated with stunting by univariate analysis were entered into the multivariable model. Several variables were not entered into the model due to multicollinearity and highly correlated with SES as they are part of socio-economic score (income, education and occupation of parents)

Significance was accepted at $P<0 \cdot 05$. Statistical analyses were conducted using the IBM Statistical Package for the Social Sciences (IBM SPSS v.20; IBM Corporation Inc).

\section{Results}

The study included 497 children aged 2-5 years who had their height and weight measured. Among the studied children, 95 (19.1\%) were stunted. Table 1 outlines the demographic characteristics of the study population and compares between stunted and non-stunted children. Children respondents' age ranged between 24 and 60 months with a mean of $40 \cdot 1$ months $(S D=11 \cdot 1)$, and the ratio of males to females was almost fifty-fifty. The perceived size at birth was lower than average for $14.3 \%$ of the studied children. Approximately one-fourth of the studied children was first-born child and one-fourth was second-born, while half of the children were ordered the third child or more. About $24 \%$ children were born before their elder sibling completed 2 years. Stunting was higher among male children as compared to female children. University graduates and postgraduates accounted for $9.2 \%$ of mothers and $17.7 \%$ of fathers of non-stunted children which were higher than $1.1 \%$ and $5.3 \%$, respectively, in children who were stunted $(P<0.001)$.

Table 2 shows that a total of $19.1 \%$ of the studied children were stunted $(\mathrm{HAZ}<-2), 1.6 \%$ were wasted and $1.8 \%$ were underweight. Overweight or obese children (weight-for-height Z-score $>+2$ ) accounted for $9.5 \%$. Nearly, $14 \%$ were obese (BMI-for-age Z-score $>+2$ ).

As shown in Table 3, stunted children of 2-3 years age group had lower mean daily intake of energy compared to non-stunted children $(4121.3 \pm 949 \mathrm{~kJ}$ compared to $4516 \cdot 1 \pm 1077 \cdot 1 \mathrm{~kJ}$, respectively) and this difference was statistically significant. In age group of $4-5$ years, the mean daily intake of protein and carbohydrates were lower in children who were stunted compared to non-stunted.

Approximately $56 \%$ of the children did not achieve the energy recommendations, while $7.4 \%$ did not achieve the protein recommendations. Among stunted group, significantly more children did not meet dietary reference intake for energy (76.3\%) and protein (13.7\%) compared to nonstunted group $(23.7 \%$ and $6 \%$, respectively). 
Table 1 Demographic characteristics of the studied children

\begin{tabular}{|c|c|c|c|c|c|c|c|c|c|c|}
\hline & \multicolumn{3}{|c|}{ Total $(n 497)$} & \multicolumn{3}{|c|}{ Stunted ( $n$ 95) } & \multicolumn{3}{|c|}{ Not stunted (n 402) } & \multirow[b]{2}{*}{$P$-value } \\
\hline & $n$ & $\%$ & Range & $n$ & $\%$ & Range & $n$ & $\%$ & Range & \\
\hline \multicolumn{11}{|l|}{ Age (months) } \\
\hline Mean & $40 \cdot 1$ & & $24.02-59.99$ & $39 \cdot 22$ & & $24 \cdot 02-59 \cdot 99$ & \multirow{2}{*}{\multicolumn{2}{|c|}{$\begin{array}{l}40 \cdot 34 \\
11.35\end{array}$}} & $24 \cdot 02-59 \cdot 99$ & 0.378 \\
\hline SD & $11 \cdot 1$ & & & $10 \cdot 08$ & & & & & & \\
\hline \multicolumn{11}{|l|}{ Sex } \\
\hline Male & 248 & $49 \cdot 9$ & & 58 & $61 \cdot 1$ & & 190 & $47 \cdot 3$ & & 0.016 \\
\hline Female & 249 & $50 \cdot 1$ & & 37 & 38.9 & & 212 & $52 \cdot 7$ & & \\
\hline \multicolumn{11}{|l|}{ Perceived size at birth } \\
\hline Lower than average & 71 & 14.3 & & 9 & 9.5 & & 62 & $15 \cdot 4$ & & \\
\hline Normal/average & 416 & 83.7 & & 84 & 88.4 & & 332 & $82 \cdot 6$ & & 0.329 \\
\hline Higher than average & 10 & $2 \cdot 0$ & & 2 & $2 \cdot 1$ & & 8 & $2 \cdot 0$ & & \\
\hline \multicolumn{11}{|l|}{ Child birth order } \\
\hline $1 \mathrm{st}$ & 129 & $26 \cdot 0$ & & 28 & 29.5 & & 101 & $25 \cdot 1$ & & \\
\hline 2nd & 119 & 23.9 & & 28 & 29.5 & & 91 & $22 \cdot 6$ & & 0.166 \\
\hline 3rd & 126 & $25 \cdot 4$ & & 23 & $24 \cdot 2$ & & 103 & $25 \cdot 6$ & & \\
\hline 4th or more & 123 & 24.7 & & 16 & $16 \cdot 8$ & & 107 & $26 \cdot 6$ & & \\
\hline \multicolumn{11}{|l|}{ Mother's education } \\
\hline Illiterate & 117 & 23.5 & & 23 & $24 \cdot 2$ & & 94 & $23 \cdot 4$ & & \\
\hline Below 2ry & 82 & $16 \cdot 5$ & & 22 & 23.2 & & 60 & 14.9 & & 0.020 \\
\hline 2ry, institute & 260 & $52 \cdot 3$ & & 49 & $51 \cdot 6$ & & 211 & $52 \cdot 5$ & & \\
\hline University, post & 38 & 7.6 & & 1 & 1.1 & & 37 & 9.2 & & \\
\hline \multicolumn{11}{|l|}{ Father's education } \\
\hline Illiterate & 77 & $15 \cdot 5$ & & 16 & $16 \cdot 8$ & & 61 & $15 \cdot 2$ & & \\
\hline Below 2ry & 91 & $18 \cdot 3$ & & 33 & 34.7 & & 58 & 14.4 & & $<0.001$ \\
\hline 2ry, institute & 265 & 53.3 & & 41 & 43.2 & & 224 & $55 \cdot 7$ & & \\
\hline University, post & 64 & $12 \cdot 9$ & & 5 & $5 \cdot 3$ & & 59 & $14 \cdot 7$ & & \\
\hline \multicolumn{11}{|l|}{ Mother's work } \\
\hline Housewives & 445 & 89.5 & & 89 & 93.7 & & 356 & 88.6 & & 0.142 \\
\hline Working & 52 & 10.5 & & 6 & $6 \cdot 3$ & & 46 & 11.4 & & \\
\hline \multicolumn{11}{|l|}{ Occupation of father } \\
\hline Non-working & 7 & 1.4 & & 0 & 0.0 & & 7 & $1 \cdot 7$ & & \\
\hline Unskilled & 97 & 19.5 & & 22 & $23 \cdot 2$ & & 75 & $18 \cdot 7$ & & 0.253 \\
\hline Skilled & 266 & 53.5 & & 56 & 58.9 & & 210 & $52 \cdot 2$ & & \\
\hline Business & 48 & 9.7 & & 8 & 8.4 & & 40 & $10 \cdot 0$ & & \\
\hline Semiprofessional & 45 & $9 \cdot 1$ & & 6 & $6 \cdot 3$ & & 39 & 9.7 & & \\
\hline Professional & 34 & $6 \cdot 8$ & & 3 & $3 \cdot 2$ & & 31 & $7 \cdot 7$ & & \\
\hline \multicolumn{11}{|l|}{ Income } \\
\hline In debt & 54 & $10 \cdot 9$ & & 17 & $17 \cdot 9$ & & 37 & 9.2 & & \\
\hline Routine & 85 & $17 \cdot 1$ & & 29 & 30.5 & & 56 & 13.9 & & $<0.001$ \\
\hline Routine + emergency & 184 & $37 \cdot 0$ & & 31 & 32.6 & & 153 & 38.1 & & \\
\hline Save money & 174 & $35 \cdot 0$ & & 18 & $18 \cdot 9$ & & 156 & $38 \cdot 8$ & & \\
\hline \multicolumn{11}{|l|}{ Socio-economic level } \\
\hline Very low $(<35)$ & 119 & 23.9 & & 32 & 33.7 & & 87 & $21 \cdot 6$ & & \\
\hline Low (35-41) & 108 & $21 \cdot 7$ & & 30 & 31.6 & & 78 & 19.4 & & $<0.001$ \\
\hline Middle (42-47) & 136 & 27.4 & & 19 & $20 \cdot 0$ & & 117 & $29 \cdot 1$ & & \\
\hline High $(\geq 48)$ & 134 & $27 \cdot 0$ & & 14 & $14 \cdot 7$ & & 120 & 29.9 & & \\
\hline
\end{tabular}

Table 2 Anthropometric measurements of the participating children

\begin{tabular}{|c|c|c|c|c|c|c|c|c|c|}
\hline & \multirow[b]{2}{*}{ Mean } & \multirow[b]{2}{*}{ SD } & \multirow[b]{2}{*}{ Range } & \multicolumn{2}{|c|}{$<-2 \mathrm{SD}$} & \multicolumn{2}{|c|}{+2 to -2 SD } & \multicolumn{2}{|c|}{$>+2 \mathrm{SD}$} \\
\hline & & & & $n$ & $\%$ & $n$ & $\%$ & $n$ & $\%$ \\
\hline HAZ & -1.03 & $1 \cdot 15$ & 4.97 to 3.65 & 95 (stunted) & $19 \cdot 1$ & 399 & $80 \cdot 3$ & 3 & 0.6 \\
\hline WHZ & 0.62 & 1.06 & -3.34 to 3.96 & 8 (wasted) & 1.6 & 442 & 88.9 & 47 & 9.5 \\
\hline WAZ & -0.15 & 0.86 & -3.39 to 2.24 & 9 (underweight) & 1.8 & 486 & 97.8 & 2 & 0.4 \\
\hline MUACZ & 0.2 & 0.87 & -2.89 to 3.09 & 10 & 2 & 477 & 96 & 10 & 2 \\
\hline BAZ & 0.74 & $1 \cdot 1$ & -3.54 to 4.44 & 9 & 1.8 & 418 & $84 \cdot 1$ & 70 & $14 \cdot 1$ \\
\hline
\end{tabular}

WAZ, weight-for-age Z-score; HAZ, height-for-age Z-score; WHZ, weight-for-height Z-score; MUAC, mid-upper arm circumference; BAZ, BMI-for-age Z-score.

Table 4 shows that children who were stunted significantly consumed poultry $(P=0.001)$, eggs $(P=0.027)$ and fruits $(P=0.001)$ less often than non-stunted children, while consumed legumes more frequently $(P=0.014)$. There were no associations between other food groups and stunting. 
Table 3 Dietary intake of children using 24-h recall

\begin{tabular}{|c|c|c|c|c|c|c|c|c|c|c|}
\hline \multirow[b]{2}{*}{ Children ( $2-3$ years) } & \multicolumn{3}{|c|}{ Total (n 204) } & \multicolumn{3}{|c|}{ Stunted (n 43) } & \multicolumn{3}{|c|}{ Not stunted ( $n$ 161) } & \multirow[b]{2}{*}{$P$-value } \\
\hline & Mean & SD & Range & Mean & SD & Range & Mean & SD & Range & \\
\hline Energy (kJ/d) & $4432 \cdot 9$ & $1103 \cdot 6$ & $2092 \cdot 9-6939 \cdot 3$ & $4121 \cdot 3$ & 949 & $2439 \cdot 1-6939 \cdot 3$ & $4516 \cdot 1$ & $1077 \cdot 1$ & $2093 \cdot 1-6902 \cdot 3$ & 0.037 \\
\hline Protein $(\mathrm{g} / \mathrm{d})$ & $28 \cdot 18$ & 9.9 & $10 \cdot 02-60.68$ & $26 \cdot 21$ & $10 \cdot 84$ & $10 \cdot 03-47.79$ & $28 \cdot 7$ & 9.6 & $10 \cdot 02-60 \cdot 68$ & 0.143 \\
\hline Fat $(g / d)$ & 36.75 & 11.86 & $6 \cdot 66-70 \cdot 83$ & 34.99 & 12.02 & $6 \cdot 66-65 \cdot 9$ & $37 \cdot 21$ & 11.82 & $10 \cdot 25-70 \cdot 83$ & 0.276 \\
\hline \multirow[t]{2}{*}{ Carbohydrates $(\mathrm{g} / \mathrm{d})$} & 151.04 & $48 \cdot 31$ & $58 \cdot 66-310 \cdot 19$ & 140.49 & 45.07 & $73.15-226.99$ & $153 \cdot 86$ & 48.88 & $58 \cdot 66-310 \cdot 19$ & 0.107 \\
\hline & \multicolumn{3}{|c|}{ Total (n 293) } & \multicolumn{3}{|c|}{ Stunted (n 52) } & \multicolumn{3}{|c|}{ Not stunted (n 241) } & \\
\hline Children (4-5 years) & Mean & $\mathrm{SD}$ & Range & Mean & SD & Range & Mean & SD & Range & $P$-value \\
\hline Energy $(\mathrm{kJ} / \mathrm{d})$ & 4891.4 & $1099 \cdot 1$ & $2261-7735 \cdot 4$ & 4389.7 & 1054.6 & $2260 \cdot 8-7108 \cdot 2$ & $4999 \cdot 7$ & $1080 \cdot 3$ & $2348.5-7735.4$ & $<0.001$ \\
\hline Protein $(\mathrm{g} / \mathrm{d})$ & 32.41 & 9.84 & $4 \cdot 2-67 \cdot 55$ & $29 \cdot 1$ & 9.04 & $12 \cdot 35-47 \cdot 45$ & $33 \cdot 12$ & 9.88 & $4.2-67.55$ & 0.007 \\
\hline Fat $(g / d)$ & $40 \cdot 14$ & 12.33 & $10.25-78.73$ & 37.78 & $10 \cdot 94$ & $16 \cdot 83-63 \cdot 34$ & $40 \cdot 66$ & 12.57 & $10 \cdot 25-78 \cdot 73$ & 0.127 \\
\hline \multirow[t]{3}{*}{ Carbohydrates $(g / d)$} & 170.08 & $47 \cdot 72$ & $58 \cdot 66-314.88$ & $147 \cdot 11$ & $43 \cdot 13$ & $69 \cdot 32-273 \cdot 16$ & $175 \cdot 04$ & $47 \cdot 29$ & $58 \cdot 66-314.88$ & $<0.001$ \\
\hline & \multicolumn{3}{|c|}{ Total (n 497) } & \multicolumn{3}{|c|}{ Stunted ( $n$ 95) } & \multicolumn{3}{|c|}{ Not stunted (n 402) } & \\
\hline & Mean & & SD & Mean & & SD & Mean & & SD & $P$-value \\
\hline Not meeting recommended energetic intake* & 279 & & $56.1 \%$ & 66 & & $76.3 \%$ & 213 & & $23.7 \%$ & 0.004 \\
\hline Not meeting recommended protein intake* & 37 & & $7.4 \%$ & 13 & & $13.7 \%$ & 24 & & $6 \%$ & 0.01 \\
\hline
\end{tabular}

$\mathrm{DRI}$, dietary reference intake.

*Based on DRI (25).

.

DRI for children aged 4-5 years: $5016 \mathrm{~kJ}(1200 \mathrm{kcal})$ and $19 \mathrm{~g}$ protein. 
Table 4 Average weekly food consumption frequency: compared by stunting in children

\begin{tabular}{|c|c|c|c|c|c|c|c|c|c|c|c|c|}
\hline \multirow{2}{*}{$\begin{array}{l}\text { Weekly food group intake } \\
\text { frequency (times/week) }\end{array}$} & \multicolumn{3}{|c|}{ Total (n 497) } & \multicolumn{3}{|c|}{ Stunted (n 95) } & \multicolumn{3}{|c|}{ Not stunted (n 402) } & \multirow[b]{2}{*}{ OR } & \multirow[b]{2}{*}{$95 \% \mathrm{Cl}$} & \multirow[b]{2}{*}{$P$-value } \\
\hline & Mean & SD & Range & Mean & SD & Range & Mean & SD & Range & & & \\
\hline Meat & 0.57 & 0.71 & $0-3.5$ & 0.47 & 0.68 & $0-3.5$ & 0.59 & 0.72 & $0-3.5$ & 0.77 & $0.54,1.09$ & 0.133 \\
\hline Poultry & 1.53 & 0.82 & $0-5.5$ & 1.26 & 0.77 & $0-3.5$ & 1.59 & 0.82 & $0-5.5$ & 0.56 & $0.41,0.77$ & $<0.001^{*}$ \\
\hline Fish & 0.19 & 0.43 & $0-2$ & 0.23 & 0.47 & $0-2$ & 0.18 & 0.42 & $0-2$ & 1.26 & $0.78,2.03$ & 0.34 \\
\hline Egg & $3 \cdot 12$ & 2.09 & $0-7$ & $2 \cdot 69$ & 2 & $0-7$ & $3 \cdot 22$ & $2 \cdot 1$ & $0-7$ & 0.88 & $0.79,0.99$ & $0.028^{*}$ \\
\hline Milk & 1.53 & $2 \cdot 24$ & $0-7$ & 1.44 & 2.42 & $0-7$ & 1.55 & $2 \cdot 19$ & $0-7$ & 0.98 & $0.88,1.08$ & 0.671 \\
\hline Milk products & 3.61 & $2 \cdot 22$ & $0-7$ & 3.56 & $2 \cdot 41$ & $0-7$ & $3 \cdot 62$ & $2 \cdot 17$ & $0-7$ & 0.99 & $0.89,1.09$ & 0.822 \\
\hline Fruits & $2 \cdot 81$ & $2 \cdot 10$ & $0-7$ & 2.08 & 1.69 & $0-7$ & 2.98 & $2 \cdot 15$ & $0-7$ & 0.78 & $0.69,0.89$ & $<0.001^{\star}$ \\
\hline Vegetables & 3.98 & 2.00 & $0.63-7$ & $3 \cdot 84$ & 2.09 & $0.63-7$ & 4.02 & 1.98 & $0 \cdot 63-7$ & 0.96 & $0.85,1.07$ & 0.436 \\
\hline Legumes & $5 \cdot 51$ & 2.04 & $0.25-7$ & 5.97 & 1.78 & $1-7$ & 5.4 & 2.09 & $0.25-7$ & 1.17 & $1.03,1.32$ & $0.016^{\star}$ \\
\hline Rice/macaroni & 3.73 & 1.63 & $0.25-7$ & 4.01 & 1.96 & $0.25-7$ & 3.67 & 1.54 & $0.25-7$ & 1.14 & $0.99,1.3$ & 0.061 \\
\hline Tubers (potatoes) & 4.67 & 1.67 & $0-7$ & 4.92 & 1.66 & $1-7$ & $4 \cdot 61$ & 1.67 & $0-7$ & 1.12 & $0.98,1.29$ & $0 \cdot 107$ \\
\hline
\end{tabular}

${ }^{\star}$ Significant difference at $P$-value $<0.05$.

Table 5 Binary logistic analysis of factors associated with stunting among the studied sample

\begin{tabular}{|c|c|c|c|c|c|c|}
\hline & \multicolumn{6}{|c|}{ Stunting } \\
\hline & Crude OR & $95 \% \mathrm{Cl}$ & $P$-value & Adjusted OR & $95 \% \mathrm{Cl}$ & $P$-value \\
\hline \multicolumn{7}{|l|}{ Child sex } \\
\hline Female & 1.00 (reference) & & & 1.00 (reference) & & \\
\hline Male & 1.75 & $1 \cdot 11,2 \cdot 76$ & $0.016^{*}$ & 1.91 & $1 \cdot 17,3 \cdot 10$ & $0.009^{*}$ \\
\hline Height of mother & 0.94 & $0.9,0.98$ & $0.002^{*}$ & 0.97 & $0.92,1.01$ & 0.139 \\
\hline $\begin{array}{l}\text { Age of mother } \\
\text { SES }\end{array}$ & 0.93 & $0.89,0.97$ & $0.001^{*}$ & 0.93 & $0.88,0.99$ & $0 \cdot 018^{*}$ \\
\hline Very low & $3 \cdot 15$ & $1 \cdot 59,6 \cdot 26$ & $0.001^{*}$ & 3.05 & $1.45,6.39$ & $0.003^{*}$ \\
\hline Low & $3 \cdot 3$ & $1.65,6 \cdot 61$ & $0.001^{*}$ & 2.74 & $1 \cdot 31,5 \cdot 72$ & $0.007^{*}$ \\
\hline Middle & 1.39 & $0.67,2.9$ & 0.378 & $1 \cdot 27$ & $0.59,2.73$ & 0.537 \\
\hline High & 1.00 (reference) & & & 1.00 (reference) & & \\
\hline $\begin{array}{l}\text { Not meeting } \\
\text { recommended protein intake }\end{array}$ & 2.5 & $1 \cdot 22,5 \cdot 11$ & $0.012^{*}$ & $2 \cdot 26$ & $1 \cdot 01,5 \cdot 05$ & $0.047^{*}$ \\
\hline $\begin{array}{l}\text { Not meeting } \\
\text { recommended } \\
\text { energetic intake }\end{array}$ & $2 \cdot 02$ & $1 \cdot 25,3 \cdot 26$ & $0.004^{*}$ & 1.65 & $0.98,2 \cdot 77$ & 0.06 \\
\hline No. of children & 0.81 & $0.68,0.98$ & $0.029^{*}$ & 0.95 & $0.75,1 \cdot 21$ & 0.684 \\
\hline \multicolumn{7}{|l|}{ Perceived size at birth } \\
\hline Lower than average & 0.58 & $0 \cdot 11,3 \cdot 18$ & 0.531 & & & \\
\hline Normal/average & 1.01 & $0.21,4.85$ & 0.988 & & & \\
\hline Higher than average & 1.00 (reference) & & & & & \\
\hline \multicolumn{7}{|l|}{ Child birth order } \\
\hline 1 st & 1.00 (reference) & & & & & \\
\hline 2nd & $1 \cdot 11$ & $0.61,2.01$ & 0.731 & & & \\
\hline 3rd & 0.81 & $0.44,1.49$ & 0.491 & & & \\
\hline 4th or more & 0.54 & $0.28,1.06$ & 0.072 & & & \\
\hline
\end{tabular}

N.B. Dependent variable stunting, SES socio-economic status.

$R^{2}=0 \cdot 158$.

*Significant difference at $P$-value $<0.05$.

Table 5 reveals that sex, mother's age, SES and not meeting recommended energy and protein were significantly associated with stunting. Male children were more likely to be stunted than female children (adjusted odds ratio $(\mathrm{aOR})=1.91,95 \% \mathrm{CI}=1 \cdot 17,3 \cdot 1)$. The increase in age of the mother by 1 year was associated with $7 \%$ decrees in the odds of child to be stunted (aOR $=0.93,95 \%$ $\mathrm{CI}=0.88,0.99)$. Children from very low and low socioeconomic households were more likely to be stunted compared to children from high socio-economic households $(\mathrm{aOR}=3.05, \mathrm{CI}=1.45,6.39$ and $\mathrm{aOR}=2.74, \mathrm{CI}=1.31$,
$5 \cdot 72$, respectively). Low protein intake was associated with stunting $(\mathrm{aOR}=2 \cdot 26, \mathrm{CI}=1 \cdot 01,5 \cdot 05)$.

\section{Discussion}

Nutritional status is a primary determinant of a child's health and well-being. The prevalence of stunting among under 5 years of age children in the current study was $19 \cdot 1 \%$ with mean HAZ of $-1 \cdot 03$. This was consistent with 
2014 EDHS which reported that $21 \%$ of children under 5 years of age were stunted with mean HAZ of $-0 \cdot 6^{(14)}$. Another similar finding was reported in Minia, where $20 \cdot 3 \%$ of children (age 6-24 months) were stunted ${ }^{(26)}$.

From the 95 children who were stunted, stunting was higher among male children as compared to female children (61.1 and 38.9\%, respectively). A similar finding was reported in 2014 EDHS $^{(14)}$, where $22.8 \%$ of males and $19.9 \%$ of females were stunted, also ${ }^{(26-28)}$ reported a similar finding. Furthermore, a meta-analysis of Demographic and Health Surveys (DHS) data from 10 sub-Saharan Africa found that stunting prevalence was $46 \%$ among boys, compared to $36 \%$ among girls ${ }^{(29)}$. On the other hand, Mahmudiono et al. (2018) reported that female children under 5 years of age were less likely to be stunted than their male counterparts (OR: 0.612) ${ }^{(30)}$. The higher prevalence of stunting among males than females was also reported in Zambia (42.4 and 37.6\%, respectively) ${ }^{(31)}$.

One possible explanation is that nutritional requirements may increase in male as they are actively playing outside house more than females ${ }^{(32)}$. Moreover, higher incidence of rates infectious diseases common among infants and young children were reported to be higher in male children and was attributed to greater male mobility ${ }^{(33)}$.

Obese children (BMI-for-age Z-score $>2$ SD) were $14.1 \%$ similar to EDHS $2014(14.9 \%)^{(14)}$. The coexistence of undernutrition and overnutrition is referred to as the double burden of malnutrition (DBMN). Although apparently paradoxical, both can emerge from the same root causes: poverty and food insecurity ${ }^{(34)}$.

Regarding the studied children, in order to interpret the dietary data in the current study, children were grouped according to their age and dietary requirements into two groups, 2-3 years and 4-5 years of age.

In the present study, the mean energy intake for children aged 2-3 years was $4432.9 \mathrm{~kJ}$, higher than $3569.7 \mathrm{~kJ}$ (854 $\mathrm{kcal})$ that was reported in Kenya for the same age group. However, children aged 4-5 years consumed less energy intake ( $4891.4 \mathrm{~kJ})$ than what was reported by the same study among children of the same age group $(5793.5 \mathrm{~kJ})^{(35)}$.

The study demonstrated that the mean daily intake of energy of both age groups were lower among children who were stunted compared to non-stunted children, while the mean daily intake of protein and carbohydrates were lower in stunted children of age group $4-5$ years. A previous study among pre-school children of an urban slum community in Dhaka, Bangladesh, showed that the average daily dietary intake of energy, protein, carbohydrate and lipid were lower in stunted children compared to non-stunted children ${ }^{(36)}$.

Among stunted group significantly more children did not meet dietary reference intake for protein $(13.7 \%) \mathrm{com}$ pared to non-stunted group (6\%) and children who did not meet recommended intake of protein were 2.26 times more likely to be stunted (AOR $=2 \cdot 26,95 \% \mathrm{CI}$ : $1 \cdot 01,5 \cdot 05$; $P=0 \cdot 047)$. Cohort study among children less than 5 years old from a rural area in Kenya found that children with a traditional dietary pattern have approximately a 2.5 to $3 \cdot 1$ times higher risk of becoming stunted compared with those with a protein-rich dietary pattern ${ }^{(37)}$.

Regarding weekly food consumption frequency, children who were stunted significantly consumed poultry, eggs and fruits less often than non-stunted children, while consumed legumes more frequently. A previous study investigating association of dietary pattern and stunting reported that dietary intakes of poultry dairy products, dried fruits and nuts were lower among stunted children compared to the non-stunted group ${ }^{(38)}$.

The quantity and nutritional quality of dietary protein well known to affect plasma levels of insulin-like growth factor I, the mediator of growth hormone, also the bone matrix proteins and growth factors, which play important roles in bone formation, are affected by dietary proteins ${ }^{(39)}$.

Dietary habits may have direct consequences on health and diseases through epigenetic processes. Previous study suggested that lower intakes of energy, protein and carbohydrate are significantly associated with increased global DNA methylation in children ${ }^{(36)}$.

The results revealed stunting was associated with sex, mother's age and education and se level. In relation to mother's age, the differences in prevalence of stunting decreased with maternal age. The study results corroborate with other studies ${ }^{(31)}$. This may be because younger mothers may tend to have poor knowledge and practices of good nutrition for young children ${ }^{(31)}$.

Regarding SES, children whose families had very low SES were three times more likely to be stunted compared to children whose families had high SES (AOR $=3.05$, 95\%CI: 1.45, 6.39; $P=0.003)$. Similarly, previous study showed that wealth status had an inverse relationship with stunting ${ }^{(31)}$

On the light of this study, it is recommended that multiple measures targeted at reducing child stunting should be taken in a bid to influence policy and conceiving of programmes. Policies and programmes should give greater attention to improving maternal education, especially among younger mothers and improve SES.

Nutrition education messages encouraging high consumption of protein sources including poultry and eggs are recommended. Preventive strategies to prevent stunting and promote adequate and healthy eating are needed.

\section{Strengths and limitations}

Amongst the strengths of this study is the relatively large sample size. This study adds to the literature on stunting and dietary intake in rural settings. Dietary assessment using 24-h dietary recall provides detailed intake data; and 
relatively small respondent burden (literacy not required). However, there are some limitations. Limitations of current study include using a 24-h dietary recall to collect the dietary data. This method has some advantages in that it is less expensive than dietary records, does not require literacy or a high level of compliance and gives detailed quantitative information about dietary intake. However, it relies on the memory of the informant, depends on an accurate report of the method of preparation, requires accurate estimation of portion sizes and depends on a highly trained and experienced interviewer ${ }^{(40)}$.

Another limitation is that the accuracy of the data depended on the respondent's memory, honesty and ability to understand the questions.

\section{Conclusion}

Egyptian children who were stunted suffer from poor dietary intake that may play an important role in their linear growth retardation. In this study, we have identified some significant risk factors that predict stunting among Egyptian children. Child-related factors include the child's sex (being male) and not meeting recommended energetic and protein requirements. Parental/household-related factors include mother's age and SES. Children with younger mothers and low socio-economic households have been associated with stunting. These results highlight the need for public health intervention programmes that provide access to sufficient, safe and nutritious food and health education focusing on families of low SES. Nutritional education on healthy eating habits and low-cost wholesome food is also recommended.

\section{Acknowledgements}

Acknowledgements: The authors would like to offer their sincere thanks to all the women and their children of Qulubba village, Minia, Egypt, for their participation in the study. Financial support: None. Conflict of Interest: There are no conflicts. Authorship: Dr E.M.M. and Dr E.M.S. had made substantial contributions to conception and design and perform analysis and interpretation of data. Dr T.A.A.R. and Dr S.F.A. participate in the result section of the paper and they had been involved in drafting the manuscript or revising it critically for important intellectual content. Ethics of buman subject participation: This study was conducted according to the guidelines laid down in the Declaration of Helsinki and all procedures involving research study participants were approved by the Ethics Research Committee, Faculty of Medicine, Minia University. The participants were informed about the nature and the purpose of the study and verbal consent was taken before the interview. All data for the women included in the study were kept confidential.

\section{References}

1. Tanner JM (1992) Growth as a measure of the nutritional and hygienic status of a population. Hormone Res Paediatr 38, $106-115$.

2. De Onis M \& Branca F (2016) Childhood stunting: a global perspective. Matern Child Nutr 12, 12-26.

3. FAO, IFAD, UNICEF et al. (2017) The State of Food Security and Nutrition in the World 2017. Building Resilience for Peace and Food Security. Rome: FAO.

4. da Silva ICM, França GV, Barros AJD et al. (2018) Socioeconomic inequalities persist despite declining stunting prevalence in low- and middle-income countries. J Nutr 148, 254-258.

5. Elsayed ET, ElKoly M, Zaghloul S et al. (2018) Predictors of stunting among children attending the National Nutrition Institute in Egypt. Egypt J Community Med 36, 45-60.

6. Seedhom AE, Mohamed ES \& Mahfouz EM (2014) Determinants of stunting among preschool children, Minia, Egypt. Int Public Health Forum 1, 6-9.

7. Millward DJ (2017) Nutrition, infection and stunting: the roles of deficiencies of individual nutrients and foods, and of inflammation, as determinants of reduced linear growth of children. Nutr Res Rev 30, 50.

8. Black RE, Victora CG, Walker SP et al. (2013) Maternal and child undernutrition and overweight in low-income and middle-income countries. Lancet 382, 427-451.

9. Tzioumis E \& Adair LS (2014) Childhood dual burden of under- and over-nutrition in low- and middle-income countries: a critical review. Food Nutr Bull 35, 230-243.

10. Rivera JA, Hotz C, González-Cossío T et al. (2003) The effect of micronutrient deficiencies on child growth: a review of results from community-based supplementation trials. J Nutr 133, 4010S-4020S.

11. Sekiyama M, Jiang H, Gunawan B et al. (2015) Double burden of malnutrition in rural west java: household-level analysis for father-child and mother-child pairs and the association with dietary intake. Nutrients 7, 5399 .

12. FAO (2017) Global Information and Early Warning System GIEWS, Crop Prospects and Food Situation. www.fao.org/ 3/a-i8278e.pdf (accessed March 2018).

13. Chakona G \& Shackleton C (2017) Minimum dietary diversity scores for women indicate micronutrient adequacy and food insecurity status in South African Towns. Nutrients 9 , 812.

14. Elzanaty \& Associates (2015) Egyptian Demography and Health Survey 2014, MOHP, Egypt. https://dhsprogram. com/pubs/pdf/FR302/FR302.pdf (accessed May 2018).

15. WHO (2008) Training Course on Child Growth Assessment. Geneva: WHO.

16. WHO (2011) Child Growth Standards. WHO Anthro and Macros: Software for Assessing Growth and Development of the World's Children. Geneva: World Health Organization; available at http://wwwwhoint/childgrowth/ software/en/ (accessed March 2018).

17. WHO (2006) WHO Child Growth Standards: Length/Height for Age, Weight-for-Age, Weight-for-Length, Weight-forHeight and Body Mass Index-for-Age, Methods and Development. Geneva: World Health Organization; available at http://www.who.int/childgrowth/standards/technical_ report/en/ (accessed May 2018).

18. Salvador Castell G, Serra-Majem L \& Ribas-Barba L (2015) What and how much do we eat? 24-hour dietary recall method. Nutr hosp 31, 46-48.

19. U. S. Food and Drug Administration (2005) Serving Sizes of Products that can Reasonably be Consumed at One Eating Occasion; Updating of Reference Amounts Customarily Consumed; Approaches for Recommending Smaller Portion Sizes Federal Register Advance Notice of Proposed Rulemaking. Silver Spring: US Food and Drug 
Administration; available at http://wwwfdagov/Food/ LabelingNutrition (accessed April 2018).

20. NutriSurvey (2007) NutriSurvey Program 2007 for Windows, SEAMEO-TROPMED RCCN-University of Indonesia. http:// www.nutrisurvey.de/ (accessed June 2018).

21. US Department of Health and Human Services \& Agriculture UDo (2015) 2015-2020 Dietary Guidelines for Americans. Washington, DC: UDHHS; available at http://health.gov/ dietaryguidelines/2015/guidelines/ (accessed August 2018).

22. Ramsey R, Giskes K, Turrell G et al. (2011) Food insecurity among adults residing in disadvantaged urban areas: potential health and dietary consequences. Public Health Nutr $\mathbf{1 5}$, 227-237.

23. El-Gilany A, El-Wehady A \& El-Wasify M (2012) Updating and validation of the socioeconomic status scale for health research in Egypt. Eastern Mediterr Health J 18, 962.

24. Fahmy S \& El-Sherbini A (1983) Determining simple parameters for social classifications for health research. Bull High Inst Public Health 13, 95-108.

25. Meyers LD, Hellwig JP \& Otten JJ (2006) Dietary Reference Intakes: The Essential Guide to Nutrient Requirements, 1st ed. Washington, DC: National Academies Press.

26. El-Amin AM, Mahfouz EM, Seedhom AE et al. (2014) The effect of maternal mental health on child nutritional status in El-Minia City. MJMR 25, 83-88.

27. Abdurahman A, Mirzaei K, Dorosty A et al. (2016) Household food insecurity may predict underweightand wasting among children aged 24-59 months. Ecol Food Nutr 55, 456.

28. Ihab AN, Rohana AJ, Wan Manan WM et al. (2013) Nutritional outcomes related to household food insecurity among mothers in rural Malaysia. J Health Popul Nutr 31, 480-489.

29. Wamani H, Åstrøm AN, Peterson S et al. (2007) Boys are more stunted than girls in Sub-Saharan Africa: a meta-analysis of 16 demographic and health surveys. BMC Pediatr $\mathbf{7}, 17$.

30. Mahmudiono T, Nindya TS, Andrias DR et al. (2018) Household food insecurity as a predictor of stunted children and overweight/obese mothers (SCOWT) in urban Indonesia. Nutrients 10, 535.

31. Mzumara B, Bwembya P, Halwiindi H et al. (2018) Factors associated with stunting among children below five years of age in Zambia: evidence from the 2014 Zambia demographic and health survey. BMC Nutr $\mathbf{4}, 51$.

32. Bork KA \& Diallo A (2017) Boys are more stunted than girls from early infancy to 3 years of age in rural Senegal. $J$ Nutr 147, 940-947.

33. WHO (2007) Addressing Sex and Gender in Epidemic-Prone Infectious Diseases. Geneva: WHO.

34. Ghattas H (2014) Food Security and Nutrition in the Context of the Global Nutrition Transition. Rome: Food and Agriculture Organization.

35. Ronoh AK, Were GM, Wakhu-Wamunga F et al. (2017) Food consumption patterns among pre-school children 3-5 years old in Mateka, Western Kenya. Food Nutr 8, 801-811.

36. Iqbal MS, Rahman S, Haque MA et al. (2019) Lower intakes of protein, carbohydrate, and energy are associated with increased global DNA methylation in 2- to 3-year-old urban slum children in Bangladesh. Maternal Child Nutr 15, e12815.

37. Tanaka J, Yoshizawa K, Hirayama K et al. (2019) Relationship between dietary patterns and stunting in preschool children: a cohort analysis from Kwale, Kenya. Public Health 173, 58-68.

38. Esfarjani $\mathrm{F}$, Roustaee R, Mohammadi-Nasrabadi $\mathrm{F}$ et al. (2013) Major dietary patterns in relation to stunting among children in Tehran, Iran. J Health Popul Nutr 31, 202-210.

39. Higashi Y, Takenaka A, Takahashi S-I et al. (1998) Effect of protein restriction on messenger RNA of insulin-like growth factor-I and insulin-like growth factor-binding proteins in liver of ovariectomized rats. Br J Nutr 79, 447-453.

40. Pérez-Escamilla R, Gubert MB, Rogers B et al. (2017) Food security measurement and governance: assessment of the usefulness of diverse food insecurity indicators for policy makers. Global Food Secur 14, 96-104. 